\title{
Corrigendum to "Hiatal Hernia Repair with Gore Bio-A Tissue Reinforcement: Our Experience"
}

\author{
Antonino Agrusa, Giorgio Romano, Giuseppe Frazzetta, \\ Daniela Chianetta, Giovanni De Vita, Giuseppe Di Buono, \\ Vincenzo Sorce, Silvia Di Giovanni, and Gaspare Gulotta
}

Dipartimento di Chirurgia Generale d'Urgenza e dei Trapianti d'Organo., U.O.C Chirurgia Generale e d'Urgenza, Azienda Ospedaliera Policlinico Universitario "Paolo Giaccone", Via Liborio Giuffrè 28, Palermo, 90100 Sicily, Italy

Correspondence should be addressed to Daniela Chianetta; chianetta83@libero.it

Received 17 November 2015; Accepted 19 November 2015

Copyright (C) 2015 Antonino Agrusa et al. This is an open access article distributed under the Creative Commons Attribution License, which permits unrestricted use, distribution, and reproduction in any medium, provided the original work is properly cited.

In the case report titled "Hiatal Hernia Repair with Gore Bio-A Tissue Reinforcement: Our Experience," [1] the correct author list should be "Antonino Agrusa, Giorgio Romano, Giuseppe Frazzetta, Daniela Chianetta, Giovanni De Vita, Giuseppe Di Buono, Vincenzo Sorce, Silvia Di Giovanni, and Gaspare Gulotta."

The first and last names of the authors were reversed. The correct names in order (first name, last name) have been shown in the front matter of the paper.

\section{References}

[1] A. Antonino, R. Giorgio, F. Giuseppe et al., "Hiatal hernia repair with gore Bio-A tissue reinforcement: our experience," Case Reports in Surgery, vol. 2014, Article ID 851278, 5 pages, 2014. 


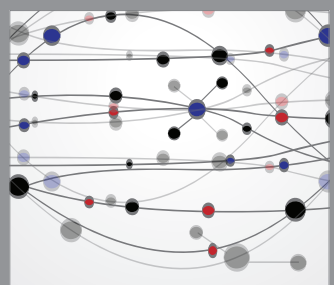

The Scientific World Journal
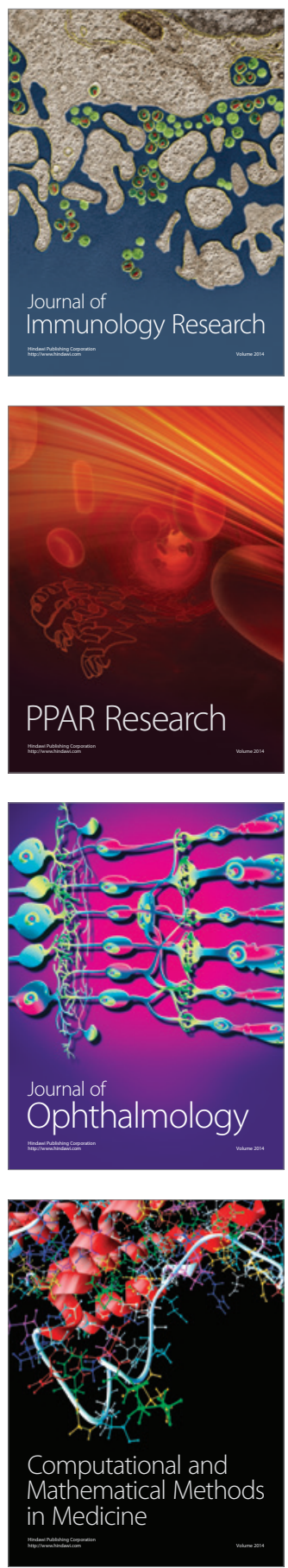

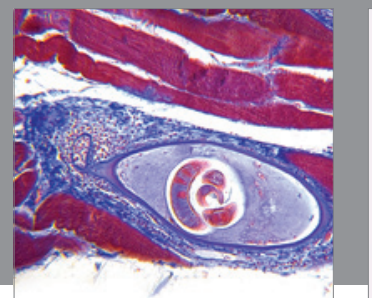

Gastroenterology

Research and Practice
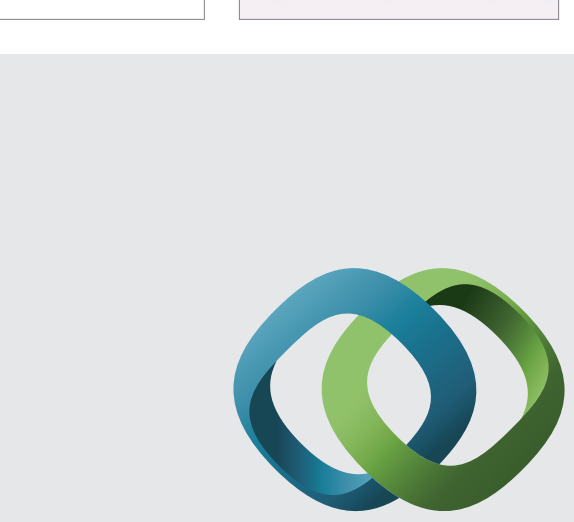

\section{Hindawi}

Submit your manuscripts at

http://www.hindawi.com
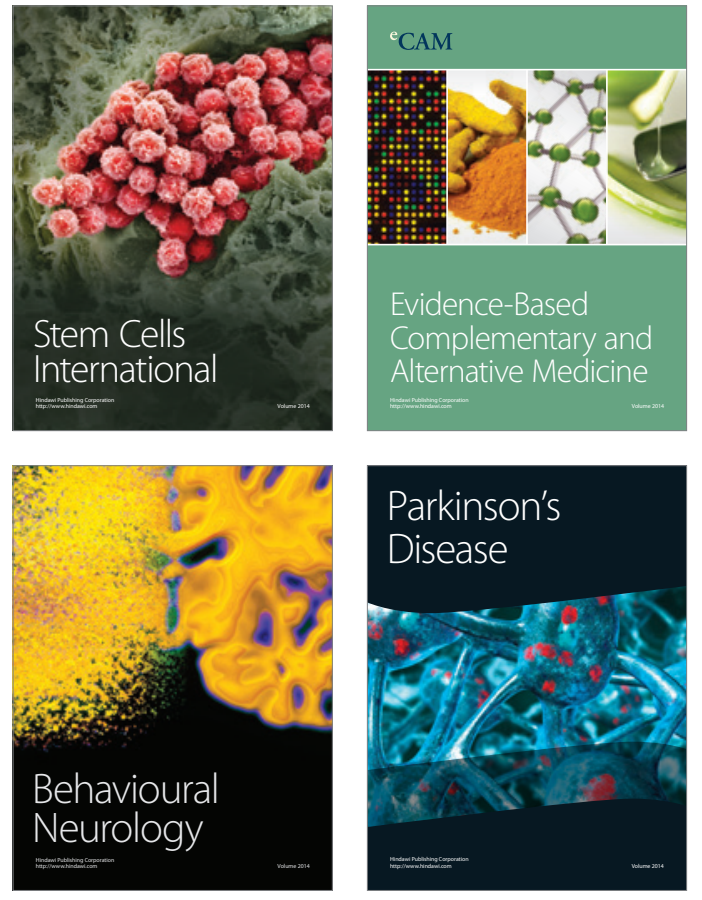
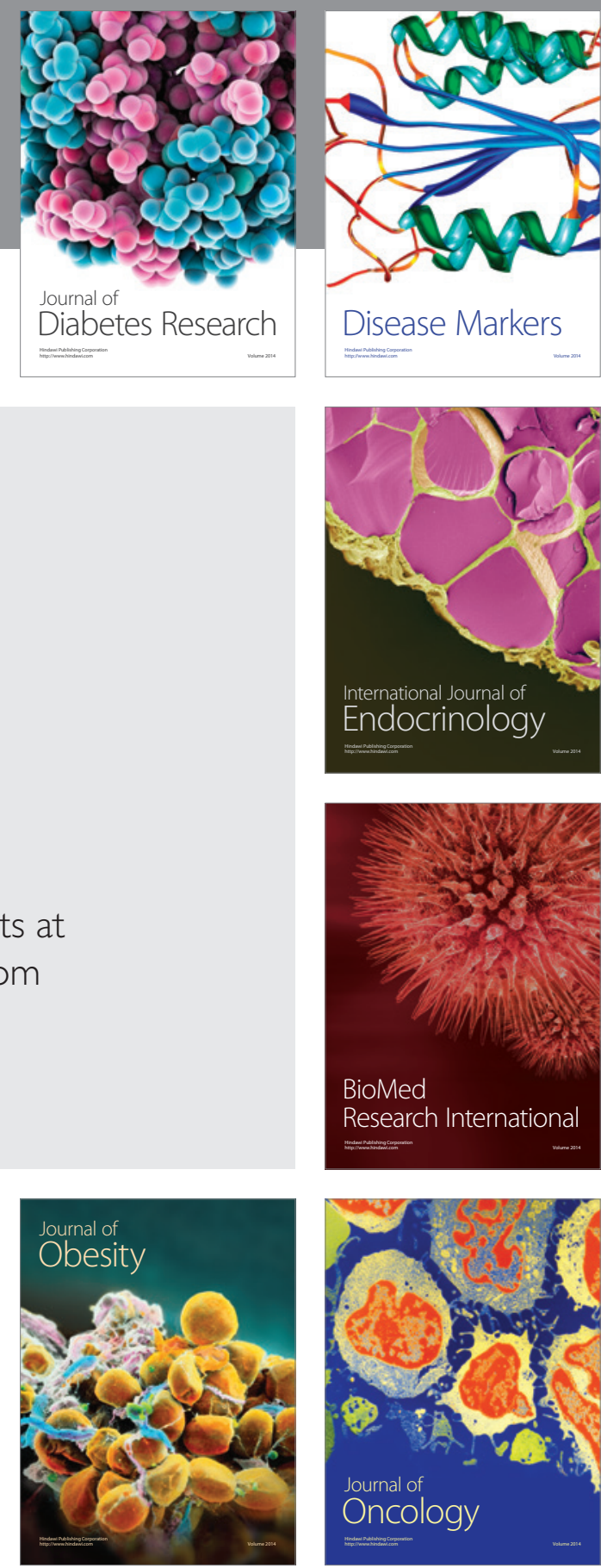

Disease Markers
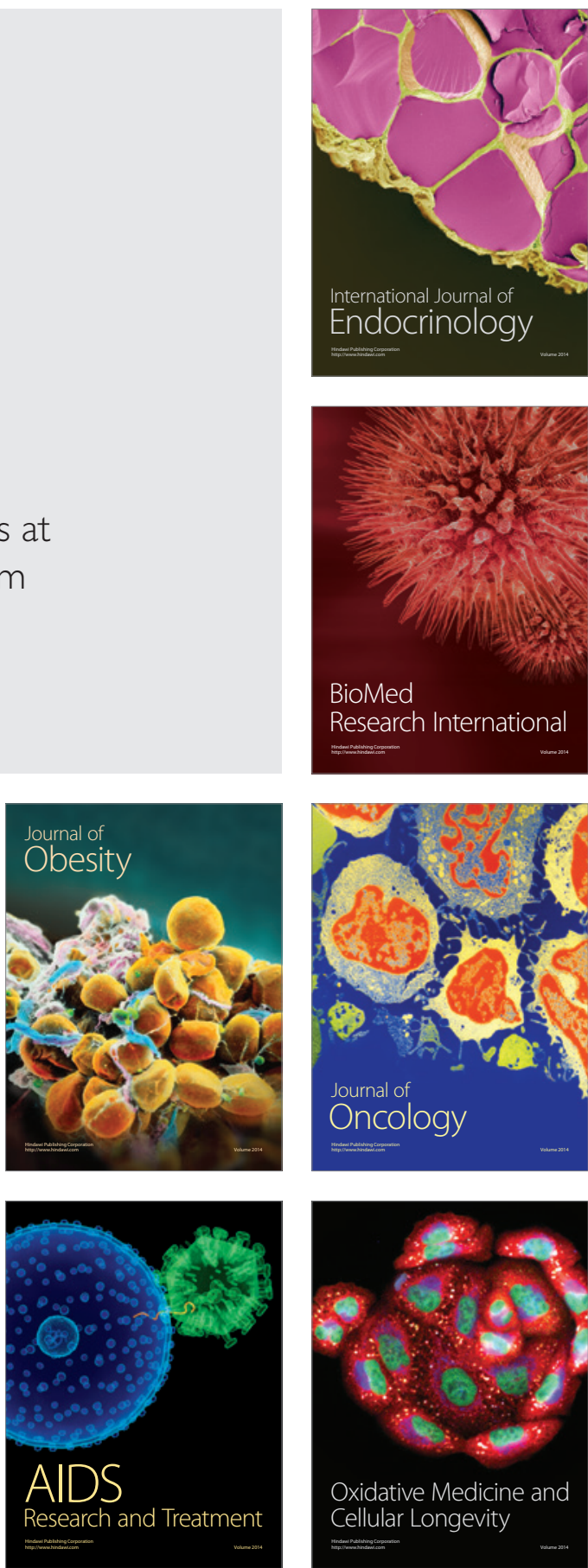